\title{
Recenzja
}

\section{Jacek H. Kołodziej, Wartości polityczne. Rozpoznanie, rozumienie, komunikowanie, Księgarnia Akademicka, Kraków 2011 , ss. 508}

Ta publikacja budzi respekt swą objętością oraz erudycją autora. Podejmuje istotne problemy, o których mówi się często, lecz nie zawsze w sposób uporządkowany.

Układ książki jest przejrzysty i logiczny. W części teoretycznej znalazły się rozważania o tym, jak można rozpoznać wartości polityczne i w jakie kategorie dają się one ujmować. Wartości polityczne zostały tam ogólnie zdefiniowane jako to, co jest w naszym życiu ważne, względem tego, co postrzegamy jako polityczne. Część empiryczna zawiera rekonstrukcję wartości politycznych odczytanych $z$ badania opinii, reklam politycznych oraz telewizyjnych serwisów informacyjnych emitowanych podczas dwóch tygodni poprzedzających wybory do Parlamentu Europejskiego w Polsce w 2009 roku.

W pierwszym rozdziale znajdujemy podejście filozoficzne: rekonstrukcję różnych prób strukturyzowania wartości, w tym dzielenia ich na podstawowe i pochodne oraz perfekcyjne i użytkowe. Przewodnikami w myśleniu o wartościach są tu zwłaszcza Roman Ingarden i Henryk Elzenberg. Rozdział drugi dotyczy podejścia socjologicznego. Wartości traktowane są jako to, co jest pożądane przez ludzi i realizowane w interakcjach, co zarazem wyznacza normy społeczne, a przez to tworzy kulturę i strukturę społeczną. Trzeci rozdział reprezentuje podejście politologiczne. Jako syntezę tego, co polityczne, Autor wyróżnił trzy sytuacje społeczne: wyzwanie spowodowane niedoborem zasobów i niezgodnością interesów różnych grup, konflikt, dominację. Dominacja, w ślad za rozumowaniem Antonio Gramsciego, została przedstawiona jako hegemonia stanowiąca połączenie przymusu i konsensu. Za Januszem Goćkowskim Autor wprowadził dodatkowo pojęcie panowania, obejmujące łącznie hegemonię (tym razem rozumianą w przybliżeniu jako legitymizacja) oraz dominację (jako posłuch rządzonych wobec oficjalnych regulacji). W rozdziale czwartym znajdujemy podejście socjotechniczne. Skoro rozwój społeczny można zaplanować i modyfikować, to wartości 
zostały uznane za ważną kategorię opisu i argumentowania na rzecz racjonalnej inżynierii społecznej.

Kolejne cztery rozdziały konkretyzują wcześniejsze ustalenia. Autor przytacza wyniki badania opinii w różnych krajach Europy świadczące o przewadze deklarowania wartości odczuciowych, hedonistycznych oraz materialno-bytowych. Przypomina, że wartości polityczne ujawniają się w kontekście symbolicznego konfliktu o tożsamości, toczonego publicznie przez aktorów politycznych. Wartości polityczne Autor wiąże z napięciem między tym, co perfekcyjne, a tym, co utylitarne, oraz między tym, co pozytywne, a tym, co negatywne. Wskazuje, że nośnikiem wartości politycznych jest język. Stwierdza, że komunikowanie wartości politycznych wyraża się w działaniach legitymizacyjnych, realizowanych przez polityków w sytuacji pluralizmu wartości. Autor rozważa też pojęcia „kultury” i „logiki mediów” oraz współczesne zjawiska dające się określić w skrócie jako marketyzacja i tabloidyzacja przekazów.

Część empiryczną otwiera staranne zreferowanie badań wartości reprezentowanych w języku, jakie prowadzili: Jadwiga Puzynina, Tomasz Krzeszowski, Jerzy Bartmiński, Michael Fleischer oraz Walery Pisarek. Następnie autor przedstawia wyniki własnych badań. Wartości deklarowane przez zwykłych ludzi zostały zrekonstruowane na podstawie wywiadów kwestionariuszowych, opartych na zbiorze 54 słów sztandarowych wyróżnionych przez Walerego Pisarka (od miłości i rodziny po korupcję i zakłamanie). 1038 respondentów udzieliło 5190 odpowiedzi. Wartości wyrażane przez polityków Autor badał, analizując wszystkie reklamy polityczne czterech najsilniejszych komitetów wyborczych (PO, PiS, SLD-UP, PSL) nadawane bez opłat w I Programie TVP podczas dwóch tygodni kampanii. Materiałem do zbadania wartości dziennikarskich były doniesienia głównych wydań serwisów informacyjnych czterech nadawców telewizyjnych (TVP1, Polsat, TVN, Trwam) wiążące się z wyborami do Parlamentu Europejskiego. W ciągu dwóch tygodni poprzedzających wybory stanowiły one od jednej trzeciej do ponad połowy całości tych serwisów.

Ponieważ wszystkie badane wypowiedzi pochodziły z tego samego okresu - dwóch tygodni podczas kampanii wyborczej do Parlamentu Europejskiego - dotyczyły wartości europejskich traktowanych jako część zbioru wartości politycznych. Na zadane podczas wywiadu pytanie o wartości europejskie 55,3\% respondentów nie potrafiło udzielić odpowiedzi. Zdecydowa- 
na większość mówiła „nie wiem”, pozostali wyrażali przekonanie, że wartości europejskie nie istnieją. Natomiast ci, którzy odpowiedzieli, wskazywali na dwie główne wartości: swobodę podróży i pracę. Na wyraźnie dalszych miejscach znalazły się: wolność, tolerancja, wspólnotowość, demokracja, solidarność itd. Zmienne demospołeczne istotnie różnicujące wypowiedzi respondentów okazały się tylko dwie: wiek oraz poziom wykształcenia.

Wartości odczytane z reklam politycznych wszystkich partii łącznie tworzą następujący ciąg: Polska, Europa, sukces, zgoda, wiedza, lokalność itd. Ponadto dla każdej z badanych partii Autor sporządził szczegółowe zestawienie deklaracji programowych oraz wartości eksponowanych w reklamach politycznych. Natomiast wartości reprezentowane w wiadomościach telewizyjnych to: konflikt, dobro własne i dobro partii, zakłamanie, zagrożenie, sukces, Polska, praca, dyskryminacja, wspólnotowość, zgoda, korupcja itd.

W konkluzji pracy autor stwierdza istnienie zbieżności między hierarchią wartości deklarowanych przez ludzi i wartości wyrażanych przez polityków oraz istnienie rozbieżności między tymi dwoma hierarchiami a hierarchią wartości reprezentowanych w wiadomościach telewizyjnych.

Można dodać, że w ten sposób zostało empirycznie potwierdzone intuicyjne spostrzeżenie Neila Postmana, że reklama nie mówi niczego o oferowanych produktach, ale mówi wszystko o lękach, upodobaniach i marzeniach potencjalnych konsumentów ${ }^{1}$. Można też rozumieć tę konkluzję jako pochwałę dziennikarstwa: ludzie deklarują swoje życzenia, politycy te życzenia podchwytują i nagłaśniają, a jedynie dziennikarze trzymają się ziemi, donosząc o konfliktach i zagrożeniach.

Książka jest bardzo pouczająca, budzi też uznanie solidny warsztat badawczy autora, stanowiący podstawę prawomocności wyników analizy. Jedyne poważniejsze zastrzeżenie może dotyczyć wspomnianej tylko przez Autora i nierozważanej szerzej kwestii rozbieżności pomiędzy różnymi systemami wartości. Na przykład ludzie wymieniają jednym tchem wolność i równość (pozycja 4 i pozycja 9 w tabeli głównych deklarowanych wartości). Pozwala im na to wiedza potoczna, jeśli rozumieć ją jako zbiór powierzchownych, fragmentarycznych i nieuzgodnionych ze sobą uogólnień, które nie tworzą spójnej całości. Politycy są trochę bardziej ostrożni: chętnie mó-

$1 \quad$ N. Postman, Zabawić się na śmierć. Dyskurs publiczny w epoce show-businessu, tłum. L. Niedzielski, Warszawa 2002, s. 183. 
wią o wolności (pozycja $14 \mathrm{w}$ tabeli wartości odczytanych z reklam politycznych), ale zamiast równości znajdujemy tylko solidarność (pozycja $19 \mathrm{w}$ tej tabeli). A dziennikarze nie mówią ani o wolności, ani o równości, skupiając się na konfliktach, dbaniu o siebie, kłamstwach, zagrożeniach i sukcesach; co najwyżej, wspominają o solidarności i demokracji (pozycja 15 i $18 \mathrm{w}$ tabeli wartości odczytany z serwisów telewizyjnych). Myślę tu o takiej niezgodnością systemów wartości, jaką zajmowali się między innymi Isaiah Berlin (Dwie koncepcje wolności), Leszek Kołakowski (Pochwała niekonsekwencji, Kultura i fetysze) oraz John Rawls (Liberalizm polityczny), lecz tych kwestii Autor nie rozpatrywał.

Drugie, drobniejsze zastrzeżenie dotyczy niezbyt precyzyjnie stosowanych przez Autora terminów dotyczących wywierania wpływu przez nadawców przekazów medialnych na odbiorców. Jeśli za Mirosławem Karwatem rozumieć perswazję jako nacisk wywierany na partnera komunikowania traktowanego jako autonomiczny i racjonalnie działający podmiot, a manipulację jako nacisk na odbiorcę traktowanego jak przedmiot ${ }^{2}$, to zbyteczne staje się pojęcie „propagandy”, przynajmniej w społeczeństwie liberalnej demokracji, gdzie propaganda oznacza bądź perswazję, bądź manipulację. Natomiast $\mathrm{w}$ społeczeństwie autorytarnym propaganda jest synonimem komunikowania politycznego. Pojęcie reklamy pochodzi z innego porządku i oznacza pewien typ komunikowania, a każde komunikowanie wiąże się z wywieraniem wpływu na odbiorcę. Jako reklamę określimy przekazy nadawane odpłatnie (lub w ramach bezpłatnego w okresie kampanii czasu antenowego), ich treść pozostaje pod kontrolą nadawcy, w reklamie dopuszczalne jest koloryzowanie rzeczywistości, a przekazy zostały oznaczone jako reklama. Zatem przedwyborcze spoty telewizyjne to reklama, a nie propaganda.

Wojciech Furman (Uniwersytet Rzeszowski)

2 M. Karwat, Sztuka manipulacji politycznej, Toruń 1999, s. 26-39. 